performing chromosome analyses, and the Westminster Hospital for accepting this patient for bone marrow transplantation.

\section{References}

1 Smith K L, Johnson W W. Classification of chronic myelocytic leukaemia in children. Cancer 1974; 34: 670-9.

2 Hardisty R M, Speed D E, Till M. Granulocy:ic leukaemia in childhood. Br J Haematol 1964; 10: 551-66.

3 Randall D L, Reiquam C W, Githens J H, Robinson A. Familial myeloproliferative disease. Am J Dis Child 1965; 110: 479-500.

4 Holton C P, Johnson W W. Chronic myelocytic leukemia in infant siblings. J Pediatr 1968; 72: 377-83.

5 Luddy R E, Champion L A A, Schwartz A D. A fatal myeloproliferative syndrome in a family with thrombo-

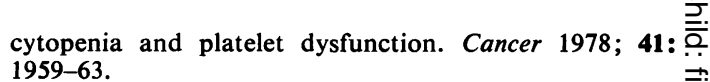

6 Inoue S, Ravindranath Y, Thompson R I, Zuelzer W W, Ottenbreit $\mathrm{M}$ J. Cytogenetics of juvenile type chronic granulocytic leukemia. Cancer 1977; 39: 2017-24.

7 Boggs D R. Hematopoietic stem cell theory in relation to possible lymphoblastic conversion of chronic myeloid $\frac{\omega}{\partial}$ leukemia. Blood 1974; 44: 449-53.

${ }^{8}$ Lambertz J, Weisgerber C, Rossier A. Syndrome myelo monocytaire du nourrisson. Ann Pediatr (Paris) 1970; $心$ 17: 436-41.

Correspondence to Dr D J Moir, Department of Haema- $\vec{\omega}$ tology, John Radcliffe Hospital, Oxford OX3 9DU.

Received 19 A.ugust 1982

\title{
Production of the hydroxylated metabolites of vitamin D in a neonate with a single hypoplastic-dysplastic kidney
}

\author{
A ALKALAY, B M MOGILNER, F NISSIM, AND S EDELSTEIN
}

\author{
Neonatal Intensive Care Unit and Department of Pathology, Kaplan Hospital, Rehovot; Biochemistry \\ Department, Weizmann Institute of Science, Rehovot, Israel
}

\begin{abstract}
SUMMARY The ability to produce dihydroxylated metabolites of vitamin D was studied in a term neonate suffering from severe renal insufficiency. The infant died at age 26 days owing to end-stage renal failure and the necropsy examination showed a single dysplastic kidney weighing $1.5 \mathrm{~g}$. At age 2 weeks the serum levels of the dihydroxylated metabolites of vitamin $\mathbf{D}$ were found to be normal and a pronounced increase was noted 24 hours after injection of 100000 IU vitamin D2. The study suggests that during the neonatal period a small renal mass is sufficient to maintain optimal circulating levels of the dihydroxylated metabolites of vitamin $D$.
\end{abstract}

The kidney is the site of the formation of the active metabolites of vitamin D. In anephric patients or in patients with end-stage chronic renal failure these metabolites are undetectable. ${ }^{2}$. We describe a neonate with a single hypoplastic dysplastic kidney, in whom the metabolism of vitamin $D$ was studied.

\section{Case report}

A 2010-g boy was born after 37 weeks of gestation with an Apgar score after one and five minutes of 6 and 8 , to a 20 -year old bedouin mother, gravida 2 , para 2, who has another healthy child. The course of the pregnancy had been normal, the amniotic fluid was meconium stained.
Immediately after birth severe respiratory distress ensued, due to bilateral pneumothorax which was drained. Chest $x$-ray film was consistent with hypoplastic lungs. Assisted ventilation was delivered $\stackrel{\mathbb{2}}{\complement}$ through an endotracheal tube, with a Baby Bird $\overrightarrow{\vec{O}}$ respirator for 10 days. At age 18 days he breathed 3 room air spontaneously. On physical examination the kidneys were not palpable and arteriography performed through the umbilical artery catheter did not reveal nephrographic effect. During the first 5 days he was anuric and afterwards oliguric.

Laboratory findings. Serum creatinine levels increased progressively from $2.2 \mathrm{mg} / 100 \mathrm{ml}(194.5 \mu \mathrm{mol} / \mathrm{l})$ on his second day to $12.3 \mathrm{mg} / 100 \mathrm{ml}(1087 \mu \mathrm{mol} / \mathrm{l})$ at 은 age 3 weeks. Other findings at between 2 and 3 weeks were: haematocrit $44 \%$, white blood count $14.0 \times$ 을 $10^{9} / 1$ with normal differential, platelets $254.0 \times 10^{9} / 1$, sodium $142 \mathrm{mmol} / 1$, potassium $4.4 \mathrm{mmol} / 1$, chloride . $102 \mathrm{mmol} / 1$, calcium $8.5 \mathrm{mg} / 100 \mathrm{ml}(2 \cdot 1 \mathrm{mmol} / \mathrm{l})$, N phosphorus $6.9 \mathrm{mg} / 100 \mathrm{ml}(2 \cdot 2 \mathrm{mmol} / \mathrm{l})$, magnesium $\mathrm{C}_{\mathrm{N}}$ $2 \mathrm{mg} / 100 \mathrm{ml}(0.822 \mathrm{mmol} / \mathrm{l})$, acid-base values about $\mathrm{O}$ pH 7.3, standard bicarbonate $19 \mathrm{mmol} / 1$, base excess $-5 \mathrm{mmol} / \mathrm{l}$. Alkaline phosphatase was $228 \mathrm{IU}$, AST $18 \mathrm{IU}$, ALT $14 \mathrm{IU}$, LDH $418 \mathrm{IU}, \stackrel{0}{?}$ 5-nucleotidase $9.8 \mathrm{IU}$, albumin $24 \mathrm{~g} / \mathrm{l}$, globulin 0 $21 \mathrm{~g} / \mathrm{l}$, prothrombin time $55 \%$, and glucose 550 $\mathrm{mg} / 100 \mathrm{ml}(3.0 \mathrm{mmol} / \mathrm{l})$.

At age 2 weeks he received 100000 IU of vitamin $\frac{\overparen{D}}{\mathbb{D}}$ D2 (Detamin) by intramuscular injection. Serum 
Table Plasma concentrations of vitamin $D$ metabolites after the administration of vitamin $D$

\begin{tabular}{ccccc}
\hline & \multicolumn{4}{l}{ Time (hours) } \\
\cline { 2 - 5 } & $0^{*}$ & 24 & 36 & 72 \\
\hline $25(\mathrm{OH}) \mathrm{D}(\mathrm{ng} / \mathrm{ml})$ & 2 & $2 \cdot 5$ & $1 \cdot 2$ & $3 \cdot 2$ \\
$1,25(\mathrm{OH})_{2} \mathrm{D}(\mathrm{pg} / \mathrm{ml})$ & 63 & 129 & 21 & 81 \\
$24,25(\mathrm{OH})_{2} \mathrm{D}(\mathrm{ng} / \mathrm{ml})$ & $1 \cdot 7$ & $6 \cdot 2$ & $4 \cdot 1$ & 2
\end{tabular}

Conversion: traditional units to $S I: 1 \mathrm{ng} / \mathrm{ml} \approx 2.5 \mathrm{nmol} / \mathrm{l}$.

* Normal basal values: $15-30 \mathrm{ng} / \mathrm{ml}$ for $25(\mathrm{OH}) \mathrm{D}$

$20-80 \mathrm{pg} / \mathrm{ml}$ for $1,25(\mathrm{OH})_{2} \mathrm{D}$

$1 \cdot 5-3 \cdot 0 \mathrm{ng} / \mathrm{ml}$ for $24,25(\mathrm{OH})_{2} \mathrm{D}$

samples were obtained at $0,24,36$, and 72 hours after injection, and subjected to lipid extraction and analysis of the metabolites of vitamin D. 25hydroxyvitamin D (25(OH)D) and 24,25-dihydroxyvitamin $\mathrm{D}\left(24,25(\mathrm{OH})_{2} \mathrm{D}\right)$ were analysed according to Edelstein et al. $^{3}$ as modified by Weisman et al.;4 1,25-dihydroxyvitamin D (1,25(OH)D) was analysed according to Eisman et al..$^{5}$ As can be seen (Table), at age 2 weeks and before the injection of vitamin D2 (0 time), the plasma concentrations of $1,25(\mathrm{OH})_{2} \mathrm{D}$ and of $24,25(\mathrm{OH})_{2} \mathrm{D}$ were within the normal range, while the concentration of $25(\mathrm{OH}) \mathrm{D}$ was low, at a range often found in rickets. ${ }^{6}$ At 24 hours after injection, there was a pronounced rise in the concentration of $1,25(\mathrm{OH}) \mathrm{D}$. At 36 and 72 hours the changes varied, but with no clear trend.

The infant's condition steadily worsened, and at age 26 days he died from end-stage kidney failure.

Necropsy examination. Gross findings disclosed single right kidney weight $1.5 \mathrm{~g}$, and consisting of a mass of cysts $0 \cdot 1-0.3 \mathrm{~cm}$ in diameter aggregated by greyish fibrous tissue. Calyces and pelvis were not present and the upper third of the ureter was stenotic.

The histological changes were consistent with renal dysplasia. There were focally dilated ducts lined by cuboidal epithelium and surrounded by concentric layers of embryonal mesenchyme. Glomeruli were almost absent, the few present having cystic, dilated Bowman's capsule and tiny, shrunken capillary tufts. In their vicinity some ducts were lined with tall and cubical epithelium with eosinophilic, somewhat granular cytoplasm, similar to the convoluted tubules of the normal kidney.

The lungs were expanded with areas of haemorrhages and intra-alveolar fibrin deposition consistent with uraemic lungs. No other congenital malformation seemed to be present in the other internal organs including the central nervous system.

\section{Discussion}

In animals and humans the dihydroxylated metabolites of vitamin $\mathrm{D}, 1,25(\mathrm{OH})_{2} \mathrm{D}$, and
$24,25(\mathrm{OH})_{2} \mathrm{D}$ are known to be formed exclusively in the kidneys, and are absent in the circulation of anephric patients, and in patients with end-stage chronic renal failure. ${ }^{12}$ The reported case shows that despite a dysplastic renal mass of only $7.5 \%$ of normal, ${ }^{7}$ the production of the dihydroxylated metabolites was not impaired. The levels of these metabolites at age 2 weeks were found to be normal, and were not likely to represent perinatal levels of maternal source as the circulating half-life of $1,25(\mathrm{OH})_{2} \mathrm{D}$, for example, is of very short duration, several hours. The circulating levels of $25(\mathrm{OH}) \mathrm{D}$ however, were found to be very low, and surprisingly only a slight increase was noted 24 hours after injection of vitamin D2. Normal response to vitamin $\mathrm{D}$ administration would be a marked increase in plasma $25(\mathrm{OH}) \mathrm{D}$ levels, a proportional increase in $24,25(\mathrm{OH})_{2} \mathrm{D}$, and no change in $1,25(\mathrm{OH})_{2} \mathrm{D}$ levels. A marked increase in circulating levels of $1,25(\mathrm{OH})_{2} \mathrm{D}$ and of $24,25(\mathrm{OH})_{2} \mathrm{D}$ was noted 24 hours after injection. The lack of increase in $25(\mathrm{OH}) \mathrm{D}$ could be due either to limited hepatic 25-hydroxylation, or the inability to maintain or store this sterol, as suggested by Hillman and Haddad. ${ }^{8}$ The increased production, particularly of $1,25(\mathrm{OH})_{2} \mathrm{D}$ after the injection of vitamin $\mathrm{D} 2$, is not surprising, as a slight increase in substrate $(25(\mathrm{OH}) \mathrm{D})$ concentrations in terms of nanograms could be sufficient to enable a pronounced increase in picograms of $1,25(\mathrm{OH})_{2} \mathrm{D}$. Possible stimulators of the conversion step include raised circulating levels of PTH, growth hormone, oestrogen, progesterone, and testosterone which were not measured.

The study suggests that during the neonatal period a very small renal mass is sufficient to maintain optimal circulating levels of the dihydroxylated metabolites of vitamin $\mathrm{D}$.

\section{References}

1 Mawer E B, Backhouse J, Taylor C M, Lumb G A, Stanbury S W. Failure of formation of 1,25-dihydroxycholecalciferol in chronic renal insufficiency. Lancet 1973; i: 626-8.

2 Taylor C M, Mawer E B, Wallace J E, St John J, Cochran M, Russell R G G, Kanis J A. The absence of 24,25-dihydroxycholecalciferol in anephric patients. Clin Sci 1978; 55: 541-7.

3 Edelstein S, Charman M, Lawson D E M, Kodicek E. Competitive protein-binding assay for 25-hydroxycholecalciferol. Clin Sci 1974; 46: 231-40.

4 Weisman Y, Reiter E, Root A. Measurement of 24,25dihydroxyvitamin $\mathrm{D}$ in sera of neonates and children. J Pediatr 1977; 91: 904-8.

5 Eisman J A, Hamstra A J, Kream B E, Deluca H F. A sensitive, precise, and convenient method for determination of 1,25 -dihydroxyvitamin $D$ in human plasma. Arch Biochem Biophys 1976; 176: 235-43.

6 Mawer E B. Clinical implications of measurements of 
circulating vitamin D metabolites. Clin Endocrinol Metab 1980; 9: 63-79.

7 Potter E L. Pathology of the fetus and infant, second edition. New York: Year Book Medical Publishers, 1961: 14.

8 Hillman L S, Haddad J G. Perinatal vitamin D metabolism. II. Serial 25-hydroxyvitamin D concentrations in sera of term and premature infants. $J$ Pediatr 1975; 86: 을 928-35.

Correspondence to $\mathrm{Dr}$ Samuel Edelstein, Biochemistry Department, Weizmann Institute of Science, Rehovot $\bar{C}$ 76 100, Israel.

Received 12 August 1982

\title{
Neonatal tetanus---long-term residual handicaps
}

\author{
P TEKNETZI, S MANIOS, AND V KATSOUYANOPOULOS \\ Department of Paediatrics, Hospital for Infectious Diseases, Thessaloniki, Greece
}

SUMMARY Thirty-eight survivors of neonatal tetanus were assessed, 5 to 12 years after recovery, for neurological sequelae, physical growth, and maturation. Apart from appreciable handicaps (cerebral palsy, mental deficit, behavioural disturbances) in 4 cases, no harmful effect on physical growth or development was found. The fact that affected patients had frequent and prolonged bouts of spasms and apnoea suggests that anoxia was the main cause of brain damage.

Generalised convulsive spasms, associated with cyanosis and apnoea and consequently with brain hypoxia, are a common and severe disorder in neonatal tetanus. It is generally believed that tetanus does not leave neurological sequelae. ${ }^{12}$ This paper presents the results of a long-term follow-up study of children who survived neonatal tetanus.

\section{Subjects and methods}

By the end of the 1970s neonatal tetanus had almost disappeared in Greece. ${ }^{3}$ This study is based on 73 children (56 of them boys) who were admitted to hospital during 1966-1977 with a clinical diagnosis of tetanus. Each came from a poor family with bad living conditions, and most of them had been delivered at home without the presence of a doctor or midwife. In every case septic cutting of the cord was the cause of the tetanus.

The presence of spasms and their management, the duration of each attack and interval between attacks, the presence of cyanosis and apnoea and the duration of each were noted. Each case was treated conservatively. Spasms were controlled by diazepam alone or in combination with barbiturates generally intravenously, by phenobarbitone, intra- muscularly or through a nasogastric tube, or by sodium phentobarbitone, intravenously, intramuscularly, or rectally. Patients were classified according to severity: 32 of them had the mild form (grade 1), 13 the moderate (grade 2), and in 28 tetanus was severe (grade 3 ). Treatment and classifi- $\underset{\infty}{\infty}$ cation are described in detail elsewhere. ${ }^{3}$

At least 3 years after leaving hospital each survivor was invited for evaluation. This comprised history since leaving hospital, a general examination (including an assessment of physical growth and development) and a neurological evaluation, as well $\mathbb{\perp}$ as a social history, psychometric, and psychological $\underset{\vec{F}}{\overrightarrow{7}}$ evaluation and an electroencephalogram (EEG). The history since leaving hospital was focused especially on the detection of possible causes of neurological involvement. Hearing was evaluated by an audiologist, using audiometry if applicable. The eyes were examined by an ophthalmologist. In addition, an evaluation of the child's speech was made.

To assess intellectual functioning we used (1) the Denver development screening test, (2) the StanfordBinet test, (3) the Wechsler intelligence scale for children, and any other tests as indicated depending on the response of the patient. For the children attending school, the results of these tests were $\sigma$ compared with school performance and social status. N Behaviour evaluation was based on information $N$ obtained from the parents as well as on the child's behaviour during the examination.

\section{Results}

There were 23 deaths, a mortality rate of $31.5 \%$; the? majority (18 of 23) had had grade 3 tetanus. Of the 50 survivors, $38(76 \%)$ attended hospital for assess- $\vec{\Phi}$ ment. In addition, information was obtained for $3 \stackrel{2}{\overparen{D}}$ other patients. One had died from pulmonary 